\title{
Enhance the Attractiveness of LAZNAS \\ Through a Quality Agricultural Empowerment Program in the Digital Era (Descriptive Analysis on LAZNAS Al-Azhar Indonesia)
}

\author{
Ning Karnawijaya and Lila Pangestu Hadiningrum \\ Institut Agama Islam Negeri (IAIN) Surakarta \\ Paper to be presented at International Conference of Zakat 2018 \\ 15-16 November, Universitas Gadjah Mada, Yogyakarta, Indonesia
}

\begin{abstract}
LAZNAS has the ability to optimize the potential of zakat in the digital era. The utilization of digital content becomes one of the strategies to increase the attractiveness of LAZNAS. Increasing the role of digital influenced by the quality of display as well as the quality of content displayed. LAZNAS strengthens the quality of content by displaying featured programs. This study aims to determine efforts to increase the attractiveness of LAZNAS through the excellent programs of agricultural empowerment conducted by LAZNAS AlAzhar in the digital era. This research uses descriptive qualitative research, using primary and secondary data sources. Data collection techniques with observation and documentation. The agriculture empowerment program of LAZNAS is an economic empowerment program in the agriculture sector that has been recognized and modeled by strategic partners such as BI, OJK, LIPI and others. Agriculture empowerment LAZNAS Al-Azhar is a qualified program with a concept that is structured, comprehensive, measurable, integrated, and sustainable. Agriculture empowerment program of LAZNAS Al-Azhar become the attraction by placing the program in the main view in every digital media utilized by LAZNAS Al-Azhar. "Gemilang Village" into the realization of an empowerment program targeting communities in proverty alleviation comprehensively. Creative ideas of agrobusiness development are developed to improve the quality and attractiveness of the program.
\end{abstract}

Keywords: empowerment, agriculture, attractiveness, LAZNAS, digital era

\section{INTRODUCTION}

Zakat, Infaq and Shodaqoh are practices in Islamic teachings that have spiritual and social dimensions. Spiritual dimension because ZIS is a religious doctrine that has the motive of merit (the good in the afterlife) and the social dimension because the giving of ZIS is craving for social and economic prosperity.

Muslim communities, especially Indonesia, are often confused with the term zakat, infaq or shodaqoh. Basically it is true that the terms zakat, infaq and shodaqoh are interrelated. Zakat is a mandatory form of alms. Shadaqoh means more broadly than zakat or infaq.
Shodaqoh can mean infaq, zakat and nonmaterial goodness or all the good / good that desires Allah's blessing. Infaq comes from the word Nafaqa which means going out, issuing something (property) for good and bad interests. From the aspect of the form of sadaqah, it is more general and can be material or non-material, while infaq is in the form of assets and zakat in the form of certain assets (BI, 2016: 62-65).

The development of zakat management is growing along with the changing conditions of Muslims in various countries and the development of understanding of the implementation of zakat in accordance with sharia. Therefore, it is necessary to have an international- 
scale fatwa regarding the model of zakat management that is in accordance with current conditions. In general, good zakat management includes three main activities, namely the collection of zakat funds, financial management and utilization of zakat. Each function has a different and specific job description. The practice of zakat management in various countries still varies, especially between countries that require zakat and countries that do not oblige. It is also different between countries whose zakat is managed directly by the government, private amil institutions or a combination of both.

The low performance of zakat is indicated by the lack of muzaki in paying zakat through the amil institution. On the other hand, muzaki in Indonesia generally pay zakat just to give up the obligation, have a tendency to pay zakat without thinking about whom the zakat is received, whether the recipient of zakat will manage the zakat well or not, for him after paying zakat, his obligations have been fulfilled. This situation tends to make the distribution of zakat through OPZ not managed professionally. As a result zakat targets managed by competent institutions to support the optimization of the collection and utilization of zakat are difficult to achieve. For this reason, more efforts are needed to raise awareness and encourage muzaki to distribute their zakat through professional OPZ. Education in muzaki basically aims to make people feel called to channel their zakat to OPZ so that they can be managed more effectively and professionally. The substance of the muzaki education is the clear communication of the utilization program, the socialization process and the way of raising funds (Ahmad, 2010).

The phenomenon of contemporary poverty and misery is generally a structural and cultural problem, so that efforts to overcome them require innovation in empowerment programs. Giving in the form of cash donations is often ineffective and needs to be transformed in the form of community development. This is in line with Qardhawi's statement (2011), which requires an acceleration of understanding of knowledge related to the world of zakat, both in terms of fiqh of zakat in order to produce jurisprudence that is in accordance with the world situation and conditions of this century.

This is where LAZIS's role is to innovate empowerment programs so that the program coverage can be in accordance with the objectives that are appropriate to the conditions of the local community, such as for education, health and productive economic activities. The main orientation of LAZIS in the distribution of zakat is the maslahah orientation and social ukhuwah. Economically the existence of zakat is to improve the welfare of the community, especially mustahik, by implementing an economic system that is in accordance with Islamic sharia or economics. Therefore LAZIS not only acts to reduce the level and severity of poverty, but plays a role in improving behavior and consumption patterns, behavior and patterns of production and investment and the distribution process that is in accordance with Islamic sharia.

The role of LAZIS must be harmonized with the industrial revolution era 4.0 which is marked by the development of globalization and technology. Its peculiarities in the digital world become a paradigm and reference for opening access and opportunities to compete globally. Competition between job seekers is increasingly difficult and the application of technology by business actors in certain sectors. This condition will increasingly create unemployment of productive age. Unemployment and poverty are very closely related besides being related to vulnerability and helplessness. To be free from poverty one must have a source of income that can be obtained by optimizing the resources they 
have both the resources in a person and the resources contained in their environment.

In reality, even though farm laborers have a family income source, with low education, narrow land ownership, farmers still occupy the lowest social strata. Thus it is necessary to improve the conditions of farm laborers by increasing the professionalism of farming in accordance with the times. LAZIS is expected to be an Islamic economic instrument that is able to build the empowerment and independence of the people in a comprehensive and sustainable manner. The existence of power filtration through assistance and empowerment is absolutely necessary. Forms of empowerment can include increased expertise (vocational), assistance (assistance), stimulants with the inclusion of assets and capital and opening access.

Through the realm of LAZNAS AlAzhar community social empowerment, it is believed and significant to be able to become a reference for government program policies in improving the welfare and food security of rural communities. Through the development of the benefits of ZIS funds through an integrative social program in the formation of a successful Gemilang village, it has transformed dozens of poor villages in Indonesia into sustainable, empowered and prosperous villages based on food security, capacity building for rural communities and improvement of village infrastructure. LASNAS Al-Azhar makes alternative financial institutions sourced from productive waqf funds in accordance with the concepts and needs of agriculture. Farmer assistance starts from the upstream production system, sub-protected product system until it reaches the market. From the above, this study seeks to examine efforts to increase the attractiveness of LAZNAS through the superior agricultural empowerment program carried out by LAZNAS Al-Azhar in the digital era.

\section{LITERATURE REVIEW}

\section{LAZ role}

The development of Zakat in the context of empowerment in Indonesia can be analyzed in value and structural aspects. The aspect of value in the management of zakat is the renewal of the concept (fiqh) of zakat. Jurisprudence of zakat is the core values in the practice of zakat management, the renewal of the object of zakat through Ijtihad (the process of deep reflection) to determine precisely and according to the assets imposed as objects of zakat in the current (modern) economic conditions. Concept renewal was also carried out in terms of law and the implementation of zakat management in the modern economy, such as the management structure of modern zis, utilization of zis funds and the use of zis funds for amil.

LAZ is a trusted institution, the distribution of zakat through zakat amil is one of the ways that efficiency and effectiveness, because LAZ is more aware of areas of poverty that are more in need, the priority of ZIS recipients. According to RI Law No. 23 of 2011 concerning Zakat Management, Zakat Management Organization is an Organization or agency that conducts planning, implementing, and coordinating activities in collecting, distributing, utilizing zakat. OPZ consists of BAZ and LAZ, in which BAZ is an institution that carries out zakat management nationally. Directly responsible to the President through the Ministry of Religion. Amil Zakat Institution according to Law No.23 of 2011 Article 17 the function / role of LAZ is an institution formed by the community that has the task of assisting the collection, distribution and utilization of zakat.

\section{Agricultural Empowerment}

World Bank, 2001 in Mardikanto and Soebianto (2015: 28) defines 
empowerment as an effort to provide opportunities and abilities to (poor) community groups, to voice or voice their opinions, ideas, or ideas, and ability and courage to choose (choice) something (concept, method, product, action).

The concept of community empowerment includes community development and community-based development. In understanding this matter first understand about empowerment and community empowerment. Community empowerment is an element that can be used by the community to survive and in a dynamic sense can develop themselves to achieve progress. While empowering the community is an effort to improve people's lives from poverty traps and underdevelopment towards an advanced society (Mardikanto and Soebiato, 2015: 40).

One important strategy in
development is the importance of
empowering
Empowerment of the community can be seen from the physical, material, economic and income aspects, institutional aspects (the growth of individual strength in the form of a group / group), the strength of cooperation, intellectual strength and the strength of joint commitment to adhere to and implement the principles of empowerment. The importance of community empowerment is to create independence, so that people are able to act, understand and apply in various development activities.

According to Harsono (2009), agricultural policy that focuses more on increasing production causes quality of life for farmers to be neglected. Agricultural policy turned out to put farmers in a down position even though farmers acted as the main players in the agricultural sector. From various studies, there are several factors that also influence farming activities, including: 1). Mental attitude, 2). Capital, 3). Market, 4). Institutional, 5). Education.
The direction of empowerment for the farming community needs to be done by developing agriculture and agroindustry or industries that process agricultural products and services that support them. Agribusiness development in Indonesia is a logical development demand and must be continued as a form of sustainability, diversification and deepening of agricultural development so far. Agribusiness development will remain relevant even if it has been achieved as high as any country's progress. Even agribusiness will be a mainstay for a country that is still difficult to relinquish its national development dependency from agriculture and rural sectors such as Indonesia.

The instrument of community empowerment in Islam is using zakat. Zakat can reduce the gap between the rich and the poor. Zakat can increase the ability to buy goods and services of poor people from not being able to buy into being able to buy goods and services, so that this can increase the demand for goods and services. In conclusion zakat is able to increase consumption and encourage economic growth (Ryandono, 2008: 26).

As of the end of 2017, zakat funds collected in Indonesia only reached Rp. 5 trillion, which is two percent of the total potential estimated to be able to reach $\mathrm{Rp}$. 217 trillion. But this figure can still be increased again, and in the context of agricultural funding this can be an alternative financing to help farmers. Conventional bank systems are deemed incompatible and not adaptive to farmers. Whereas the current conditions, the workforce in the agricultural sector is the biggest, then as a solution to institutions such as LAZ is an alternative to empower farmers. The digital era needs to be utilized in financial inclusion to bridge the gap in the distribution of financing so that the industrial revolution 4.0 will be able to create civilization, optimize what already exists, and connect it to each other especially in optimizing the role of LAZ in 
empowering the agricultural sector (Republika September 172018 https: // www.republika.co.id/berita/duniaislam/wakaf/18/05/03/p84lqa374-danazakat-untuk-pembanai-pertanian).

With the increasing role of LAZ in empowering the farming community, it is expected that the farming community will be able to improve living standards and be able to improve the quality of the family and become a production granary for National Food security. In addition, the improvement of the empowerment of farmer communities in the development of the economy is expected to avoid the problem of poverty that has so far wrapped up farmers in Indonesia.

Zakat has long been an interesting object of study. Therefore various studies around zakat have been done quite a lot, both on the theoretical plane and on the empirical plain. Research on the role of LAZIS was carried out by Ahmad Danu Syahputra (2016: 49-56) with the title LAZISMU's role in eradicating the poverty of the D.I community. Yogyakarta, which concluded that LAZISMU Yogyakarta and the collaborating institutions have a role in increasing the economic income of the Yogyakarta community, namely by carrying out existing programs and by providing additional capital in the form of grants and qardul hasan, training, and providing continuous guidance so that the community is lifted from line of poverty.

Other studies specifically addressing the optimization of zakat institutions include Prayitno's (2008) research on the Regional Zakat Agency, Muna Regency, Southeast Sulawesi Province. This study discusses in detail the management of ZIS in the BAZDA of Muna Regency which is reviewed according to the Law on management. Wiryanitri (2005) examined the role of the Zakat Agency in Sragen Province in Central Java Province in an effort to change the status of mustahik to become muzakki according to Law Number 38 of 1999. The results show that zakat management is sufficiently well proven from which funds collection, distribution and utilization of zakah which It is expected that within three years the Mustahik (recipients of zakat) can change to Muzakki (granting zakat).

Article from Mansur Efendi, 2018 with the title Islamic development philanthropy in digital era: new stategy of fund raising and program supervision stating that "Islamic philanthropy is able to develop rapidly and achieve wider success through a new strategy. The main aspect of new strategy model must be synchronized to Islamic laws embedded in the Quran and the Hadith for avoiding inappropriately ways and debatable rules. "

This research is different from a number of previous studies, especially on the research focus on the attractiveness of LAZNAS through the superior agricultural empowerment program carried out by LAZNAS Al-Azhar in the digital era.

\section{METHODOLOGY}

This research includes field research (field research). Hadi (2001) states that field research is research whose data sources are obtained directly from the field by collecting information directly and the object of research. In this study, LAZNAS Al-Azhar became its data source.

The approach used in this study is sociological normative. The normative approach is meant by referring to the legislation and Islamic concepts related to Zakat, infaq and shadaqah. Whereas what is meant by the sociological approach in this research is the research on the development of zakat empowerment in agricultural programs in the digital era as seen from the suitability of the content and suitability encountered in the field.

This research is descriptiveanalytic (Sudarto, 1996: 54) which is a research that describes clearly and in detail the phenomena that are the subject matter without performing a hypothesis or 
statistical calculation, specifically. This study intends to describe and describe in general about the attractiveness of LAZNAS through superior agricultural empowerment programs conducted by LAZNAS Al-Azhar in the digital era, then systematically study the suitability of content on the web and in the field. The location of this research was conducted at LASNAS Al-Azhar especially in the agribusiness flagship program in Desa Gemilang.

The data used includes primary data (Moleong, 1990: 112) obtained through informants in certain social situations who are selected purposively by choosing informants who meet the following criteria: (1) understanding and mastering the issues of zakat management; (2) is directly involved in agricultural empowerment activities carried out by LAZNAS Al-Azhar. The secondary data (Soeratno \& Arsyad, 2003: 76) is obtained by searching the literature that has relevance to the problem being studied, either in the form of books, theses, papers, journals, magazines, websites or other print data related to empowerment. agriculture carried out by LAZNAS AlAzhar

Data collection techniques were carried out by interviewing the managers of Al-Azhar LAZNAS agricultural empowerment. The observation method is also used so that the existing problems can be examined directly at the Al-Azhar National Institute of National Examination. While the documentation method is carried out by collecting data through documents relating to the object of this research study.

The technical analysis used is qualitative analysis using an inductive mindset. This technique is implemented using an interactive method (Miles, Huberman, \& Saldaña, 2014) which consists of three types of activities, namely data reduction, data presentation and conclusion drawing, which is carried out at the time, before and during data collection.
Data reduction is defined as the selection process, focusing on simplifying, abstracting and transforming rough data that appears from written records in the field. Presentation of data from a collection of information is carried out to provide the possibility of drawing conclusions and taking action (Miles et al., 2014).

\section{RESULTS \& DISCUSSION}

\section{Profile of LAZNAS Al-Azhar}

LAZNAS Al-Azhar has been confirmed to be a National scale Alms Zakat Institution according to the RI Minister of Religion Decree Number 240 of 2016 dated May 23, 2016. LAZNAS Al-Azhar's Vision is to become a trusted Alms Zakat Institution in the management of zakat, infaq and shadaqah funds to improve community empowerment. While the LAZNAS AlAzhar mission was first, developing zakat education, infaq, almsgiving, endowments and technology-based character services. Second, developing a comprehensive, measurable, and sustainable program to encourage community empowerment based on local wisdom. Third, improving the accountability of institutional performance through strengthening systems and management that are supported by professional human resources. Fourth, building a sustainable partnership with ABCG (Academic, Business, Civil society, Government) in the implementation of the program.

The LAZNAS Al-Azhar Grand Strategy is to support social development (education, health, economy) and morals by empowering and synergizing community potentials, providing characterized products and services, increasing income and funding sources.

The characters of LAZNAS AlAzhar which are always promoted in each program are UMMAT (Universal, Benefits, Martabat, Amanah and Tabligh). 
Universal, serving wholeheartedly in all aspects of human life that apply in every place and time as the implementation of Islamic values that rahmatan lil'alamin. Benefits, always trying to provide benefits to others. Dignity, upholds the dignity of amil, muzakki, and beneficiaries. Trustful, full of responsibility in carrying out duties and serving the ummah. Tabligh, educate, enlighten, foster, and motivate yourself and society to be better.

LAZNAS AL-Azhar's vision and mission is realized in five clusters of utilizing Islamic social funds (ziswaf) with sustainable prosperity plan. First cluster, poverty alleviation and rural community empowerment. Second cluster, alleviating unemployment and empowering productive age. Third cluster, improve the living conditions of orphans and poor people. The fourth cluster, economic empowerment, infrastructure and environmental conservation. And fifth, disaster management and volunteer networks.

Al-Azhar LAZNAS Program in the Digital Era

LAZNAS Executive Director Al Azhar Sigit Iko Sugondo said that the rapid development of technology today has changed the behavior of most people. Therefore, the growth and development of the organization must adjust to this situation. Growth management must be able to respond to and anticipate the behavior of people who are so fast following technological developments. The management of the growth of $\mathrm{Al}$ Azhar LAZNAS organization is a combination of growth due to the implications of the impact of technology applications with growth due to the impact of management processes that have undergone modifications and innovations to adjust needs.

Technology applications through display on digital media are powerful supporting factors in driving organizational growth. Because through the appearance of digital media, stakeholders and potential stakeholders know the existence of LAZNAS organization. The use of digital content is one strategy in an effort to increase the attractiveness of LAZNAS. Along with the increasing role of digital media, there needs to be attention from LAZNAS so as not to get stuck on the quality of the display on digital media which is good and interesting. However, LAZNAS must also pay attention to the real quality of the content displayed.

LAZNAS utilizes digital media by displaying excellent programs that are expected to increase stakeholder trust and attract potential stakeholders. LAZNAS Al-Azhar presents an agricultural empowerment program as a flagship program that often appears on digital media that it uses. Given that Indonesia is an agrarian country, this display is certainly very interesting. Because even though it is an agricultural country, it is precisely poverty experienced by farmers as the central actors of the agricultural sector. This will be the main attraction for stakeholders in the midst of rampant amil zakat institutions that may prioritize charity or social programs only. On the other hand, this program is very interesting considering that AL-Azhar is very synonymous with middle to upper elite communities. So that the existence of this program shows that there is concern for the elite community towards empowering middle-class farmers. As with the character of the "dignity" that they uphold, through this agricultural empowerment program, it is not only to support but empower the weak (farmers) so that the dignity of the farmers will increase with the empowerment program. 


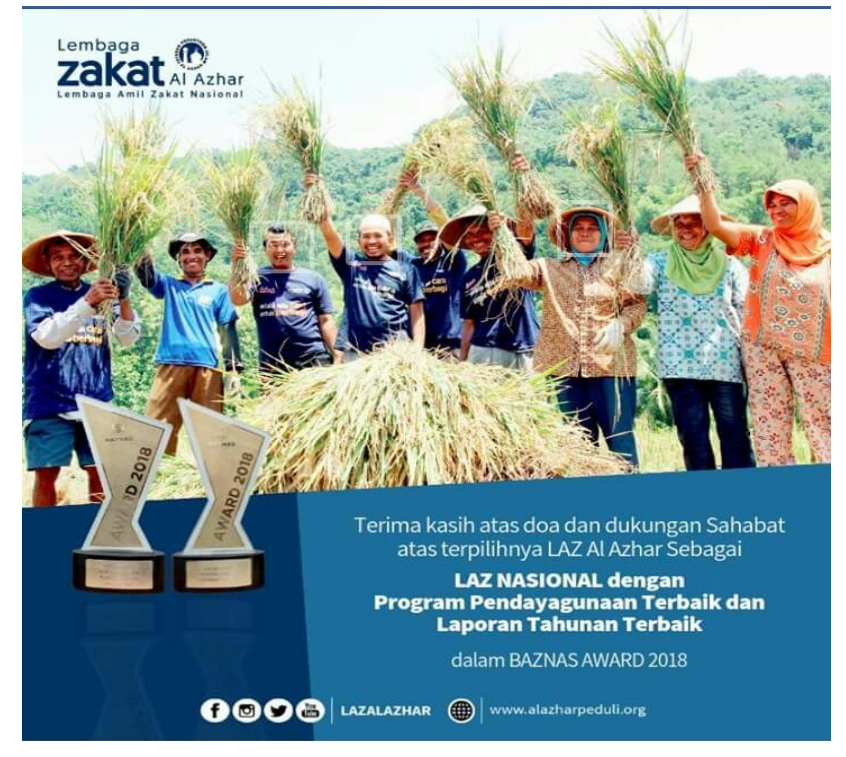

Attractiveness of the Al-Azhar LAZNAS Quality Agriculture Empowerment Program

The Al-Azhar LAZNAS empowerment program in economic empowerment has been recognized and used as a model by ABCG strategic partners (Academic, Business, Civil society, and Government). Recognition from stakeholders is certainly inseparable from the attractiveness of this program. The attraction is not only in terms of the appearance of the digital media. With the acknowledgment from government stakeholders such as BI and OJK, it shows that what LAZNAS AlAzhar displayed on the main display in digital media has been successfully implemented and has proven its quality.

"Desa Gemilang" is the embodiment of an economic empowerment program that invites special attraction for stakeholders. Desa Gemilang (the term for the guided village of LAZNAS Al-Azhar) is a program that targets the community in poverty alleviation comprehensively. In the economic sector, LAZNAS Al-Azhar focuses on the great potential of agriculture in the village. Farmer empowerment program in the gemilang village is realized by the existence of Saung Ilmu and DASAMAS (Da'I Sahabat
Masyarakat who play a role in assisting the community to realize the Gemilang Village). DASAMAS is the selected human resource that has been fostered by LAZNAS Al-Azhar with multitalent capabilities namely having the ability and knowledge in the field of religion and professionals in agriculture. The existence of Saung Ilmu and DASAMAS has an important and strategic role in building a glorious village.

Saung Ilmu is a local institution as the center of interaction between the community and the center of sharing knowledge and skills of the community. Saung Ilmu as the center of activities and program monitoring becomes very important in building the empowerment of all elements of society. Saung Ilmu is accompanied by DASAMAS who will provide, direction and guidance for the realization of Gemilang Village. DASAMAS lives with the community and mingles with the community. Dai is not only in the mosque, in the taklim assembly, or in the landfill, but is present in the fields, to plantations, to fisheries, and so on.

In Saung Ilmu there is a community group that results from the potential of the village which has positive prospects to be developed such as livestock groups, farmer groups, homegrown groups, and others. The community potential group together with DASAMAS will work together in Saung Ilmu, together to create the Gemilang Village. Forms of assistance to farmers are carried out by increasing knowledge, training in organic farming, assisting in the manufacture of mortar houses from animal waste, procurement of organic medicines, rice barns and others. The indicator of the success of this agricultural empowerment program is the increasingly independent of the built rural communities in providing their basic necessities of life by having a good food security system.

Here are some interesting programs and activities that have been implemented 
by the assisted villages of LAZNAS AlAzhar in realizing Gemilang Village:

1. Dapur Hidup, which encourages residents to use home yards to plant various vegetables. The goal is to fulfill nutrition and reduce the number of family spending. In Baran Mundu Hamlet, Puloharjo, Eromoko, Wonogiri, this program was further supported by the Gemah Ripah Savings (TGR) to utilize the abundance of vegetables when the harvest arrived. TGR is a community savings account in the form of horticultural crops polybags planted in the house and other agricultural products. The commodity savings are in the form of chillies, eggplants, tomatoes etc. which are deposited into Saung Ilmu which is recorded in a savings book and after being collected it is sold to traders. "The vegetables are saved, the balance is millions". The program initiated by DASAMAS is able to build the habit of saving and increasing family income.

2. Fertilizer house, which is the place of production and manufacture of organic fertilizer in the target village. Fertilizer houses strongly support the success of agricultural empowerment. With the presence of fertilizer houses, support for fertilizer needs to increase yields can be met. An example is the Rabuk Umbaran House in the village of Baran Mundu, Puloharjo, Eromoko, Wonogiri. This village has become an independent fertilizer village and the farmers have used solid organic fertilizers produced independently by the community. With the use of organic fertilizer has increased the yield of rice and other agricultural products both in quality and quantity

(https://www.republika.co.id/berita/dun ia-islam/wakaf/15/02/17/njwna9alazhar-peduli-umat-bangun-rumahrabuk-di-desa-gemilang).

3. Lumbung Padi. The following are examples of the success of the rice barn program that is able to improve the food security of rural communities:

a. Pelakat Village, Semende Darat Ulu, Muara Enim, South Sumatra. In this village each family has at least 1 hectare of rice fields and one rice barn, or there is famous for its bad debt. Tengkiang will be filled with rice that is still stemmed with the appropriate water content and stored until the next rice harvest. This is how they store food supplies, safely stored in the rice barn for 1-2 years. This village also received the Proklim Village award, one of the indicators of which is food security and renewable energy.

b. Dondong Village, Kesugihan, Cilacap, Central Java. The rice barn in the village is named "Lumbung Krismon" which functions as a social barn. When the harvest time arrives, each family must deposit $5 \mathrm{~kg}$ of harvested rice in the form of milled unhulled rice (GKG) to the Lumbung Krismon managed by the community. If there are people who have famine or economic difficulties, they can ask for their family's grain rations as loans. Then must return when harvesting the rice fields arrived, without having to add anything. Residents who are not farmers can participate by depositing rice by buying $5 \mathrm{~kg}$ of grain from local farmers and depositing it into the krismon granary. And if there is one of the residents who died, they will be given assistance in the form of grain to ease the burden on their families (http://www.alazhar.or.id/index.php/berita/beritaterkini/read/2016/10/07/Lumbung Padi Bisa Jadi Lumbung Sosial Hingga Gaji).

4. Rumah Pembiayaan Petani (RPP). In the management of waqf, Bank Indonesia (BI) through the Islamic Economic and Financial Council (DEKS) made LAZNAS Al Azhar as a 
partner in empowering farmers by presenting Rumah Pembiayaan Petani (RPP). RPP is an alternative funding source for farmers as one of the efforts to prosper the farmers in Indonesia. Through this RPP, at the beginning of the planting period, some of the farmers' harvests have been purchased by the RPP management with a range of $40 \%$ of the average harvest or area in the previous season through a delay scheme or a greeting contract. The price is according to the agreement of the farmers to be mutually beneficial. If the harvest arrives, farmers then hand over $40 \%$ of their crops. The rest can then be sold. This is a condition that farmers long for so far, can get a price that is suitable for their harvest even during the harvest. Risks from this model, such as crop failure are overcome by strengthening the system of food security and local community institutions, namely at the initial stage of program implementation, farmers have been conditioned to store harvests for their food reserves. And some are sold for farmers' working capital. Meanwhile for the local institutional strengthening system by applying tabarru funds' which is devoted to helping each other in the event of a disaster. So if there is a crop failure farmers still have reserves of grain in the warehouse and there are tabarru funds in the group. (Care edisi Maret 2018 dalam Warta Al-Azhar edisi: 292//April 2018, "RPP Solusi Bagi Kesejahteraan Petani" hal.6-7).

5. Interlink Rural Development Program in Kusan Hulu District, Tanah Bumbu, South Kalimantan. That is the concept of regional empowerment based on potential in each village. Seven Gemilang Villages in Kusan Hulu, became an integrated area accompanied by LAZNAS Al-Azhar. The Food Availability Program in this region is carried out in an integrated manner which includes the availability sub- system, distribution sub-system and consumption sub-system (https://www.republika.co.id/berita/dun ia-islam/wakaf/17/04/18/oolcp3374-lazal-azhar-kembangkan-kawasanpedesaan-berbasis-pertanian).

Agriculture carried by LAZNAS Al-Azhar is environmentally friendly agriculture by reducing the use of chemicals in agriculture. Therefore, LAZNAS Al-Azhar encourages people to do organic farming. In addition, LAZNAS is seriously synergizing with scientists and academics to share knowledge to help make this empowerment program successful. The synergies that have been carried out by LAZNAS Al-Azhar with scientists and academies include collaboration with Dr. Agus Kencaka DEA, teaching staff at the Faculty of Mathematics and Natural Sciences UGM who have developed new breakthroughs in making biochar-based fertilizers. Biochar content in fertilizer which is named Organic Paramagnetic Slow Release (SROP) is able to improve physical, chemical and biological properties and absorb carbon in the air (https://www.republika.co.id/berita/duniaislam/wakaf/16/09/08/od673s396-laz-alazhar-cetak-petani-sejati).

The achievements of LAZNAS AlAzhar in the Indonesia Gemilang program, developing Indonesia from the village, based on the annual Report as of December 2017 were 13,266 families. Program beneficiaries, 30 villages transformed into glorious, 11 provinces spread into models, 30 DASAMAS facilitators aligned the village community, and 30 Saung Ilmu is moving into a village knowledge center.

Based on the description above, LAZNAS Al-Azhar's agricultural empowerment program through "Desa Gemilang" is a quality program with a structured, comprehensive, measurable, integrated and sustainable concept. Structured, the agricultural empowerment program through Desa Gemilang is a 
program that is structured in a systematic, logical, simple and easy to understand manner. All potentials are knitted, so that in Saung Ilmu all components of the community discuss, design village progress for three years. Then it is lowered in per year, and is evaluated every three months

(https://chanelmuslim.com/infobisnis/lazna s-al-azhar-sebagai-katalisator-antara-desapemerintah-dan-lembaga-pembiayaan).

Comprehensive, integrated rural community empowerment based on the potential that exists in the community in an area. Village assistance by DASAMAS seeks to realize the overall welfare of the community based on economic empowerment and village potential supported by knowledge and skills in the field of religion and agriculture.

Measured, monitoring and evaluation of the results of outputs and outcomes is carried out continuously by looking at the indicators of success in utilizing zakat funds to have a positive impact on the empowerment of farmers in the village. Each village has different progress, because each village has its own uniqueness. Empowerment is targeted for three years and can then be submitted to local cadres.

Integrated, Saung Ilmu and community assistants (DASAMAS) have an important and strategic role in building Gemilang Village. DASAMAS as an arm of LAZNAS integrates with the community and stakeholders in the implementation of the program in the target villages.

Sustainable, the Desa Gemilang program pioneered by LAZNAS Al-Azhar is sustainable, both by empowerment that is continued by local cadres and the sustainability of the program by carrying out mentoring in other assisted villages that require empowerment.

Agricultural empowerment programs that have been carried out by LAZNAS Al-Azhar, prove that LAZNAS Al-Azhar not only pays attention to digital content but also presents quality empowerment programs in accordance with the appearance of digital media used. In this case, the main display of LAZNAS Al-Azhar in digital media by displaying farmer empowerment is balanced with the implementation of quality agricultural programs that show real results. Thus, it is able to attract stakeholders with the achievements and success of the program.

The results and achievements that have been achieved become challenges and motivations for LAZNAS Al Azhar to continue to provide excellent service to mustahik, muzakki and other stakeholders in an effort to optimize zakat to realize community welfare and alleviate poverty. Thus, stakeholder trust will be maintained at LAZNAS Al-Azhar as a trusted philanthropic institution in managing ziswaf funds to improve community empowerment.

Creative and innovative ideas in terms of both the appearance of digital media and the development of agribusiness programs that are carried out in real terms must continue to be improved. With a variety of new ideas and more innovative empowerment concepts, it is expected to be able to create a higher quality agricultural financing program. In terms of appearance, it is also important, that is by displaying the successes of the assisted villages in agricultural empowerment will make stakeholders and prospective stakeholders will have an interest in being involved and participating with LAZNAS to succeed these empowerment programs. Thus, to increase the attractiveness of LAZNAS, especially for stakeholders and potential stakeholders in this digital era, it needs to be supported by the appearance of attractive digital media and real quality agricultural empowerment programs.

\section{CONCLUSION}

The development of technology is a must to be followed for the growth and 
existence of LAZNAS. The digital era demands the professionalism of LAZNAS managers in utilizing digital media in their role in driving the progress of LAZNAS programs. Content on digital media is an important factor in increasing the attractiveness of LAZNAS. The important thing that has been the concern of LAZNAS Al-Azhar in utilizing digital media that is able to increase the attractiveness of LAZNAS is:

1. Display of superior agricultural empowerment programs on the main display in digital media, namely a display that reflects the success of farmers' empowerment.

2. The realization of the flagship program shown in the form of quality agricultural empowerment is a structured, comprehensive, measurable, integrated and sustainable agricultural empowerment program.

3. Creative and innovative ideas of agricultural empowerment programs that continue to be developed.

Recognition from stakeholders of ABCG (Academic, Business, Civil Society, and Government) is a real proof of the seriousness of LAZNAS Al-Azhar in balancing the quality of the display and the real quality of program implementation as the content is displayed. Thus, it will increase the attractiveness and trust of stakeholders and potential stakeholders towards LAZNAS Al-Azhar.

\section{REFERENCES}

Ahmad Juwaini dalam Tim Penulis IZDR, 2010. Indonesia Zakat \& Development Report 2010 Menggagas Arsitektur Zakat Indonesia: Menuju Sinergi Pemerintah dan Masyarakat Sipil Dalam Pengelolaan Zakat Nasional.IMZ, Ciputat.

Ahmad Danu Syaputra, 2016. Peranan LAZISMU dalam mengentaskan kemiskinan masyarakat D.I.
Yogyakarta. Journal of Islamic Economics Lariba (2016). vol. 2, issue 2: 49-56

Al-Azhar.or.id. 2016. Lumbung padi Bisa Jadi Lumbung Sosial Hingga Gaji. Diakses dari http://www.alazhar.or.id/index.php/berita/beritaterkini/read/2016/10/07/Lumbung Padi Bisa Jadi Lumbung Sosial Hingga Gaji

BI. 2016. Pengelolaan Zakat yang Efektif: Konsep dan Praktik di Beberapa Negara. Jakarta:Departemen Ekonomi dan Keuangan Syariah-BI

Care edisi Maret 2018 dalam Warta AlAzhar edisi: 292//April 2018, "RPP Solusi Bagi Kesejahteraan Petani" hal.6-7

Chanelmuslim.com. 2016. Laznas AlAzhar sebagai Katalisator antara Desa, Pemerintah dan Lembaga Pembiyayaan. Diakses dari https://chanelmuslim.com/infobis nis/laznas-al-azhar-sebagaikatalisator-antara-desapemerintah-dan-lembagapembiayaan.

Hadi, S. 2001. Metodologi penelitian.

Yogyakarta, Indonesia: Fakultas

Psikologi

Universitas Gadjah Mada.

Harsono 2009, Distribusi Pendapatan dan Pertumbuhan Ekonomi Petani, CV Rajawali Jakarta.

Miles, M. B., Huberman, A. M., \& Saldaña, J. 2014. Qualitative data analysis: Amethodssourcebook. SAGE Publications, Inc. New York, US: SAGE Publications. Retrieved from http://www. sagepub.com/books/Book239534? course $=$ Course $10 \&$ product Type $=$ Books\&sortBy $=$ defa ultPubDate desc $\&$ fs $=1$ \#tabview $=$ google

Mardikanto, Totok dan Poerwoko Soebiato. 2015. Pemberdayaan Masyarakat Dalam Perspektif Kebijakan Publik. Edisi Revisi. Bandung:Alfabeta. 
Mansue Efendi. 2018. Islamic Philantrophy Development in Digital Era. Paper yang dipresentasikan dalam International Seminar On Sharia, Law, and Muslim Societies ISSLAMS. 8 Mei 2018. IAIN Surakarta

Moleong, L. J. (1990). Metodologi penulisan kualitatif. Bandung, Indonesia: Tarsito.

Prayitno, B. (2008). Optimalisasi pengelolaan zakat pada badan amil zakat daerah (Tinjauan terhadap Badan Amil Zakat Daerah Kabupaten Muna Propinsi Sulawesi Tenggara). Universitas Diponegoro [M.A. Thesis]. Retrieved from http://eprints.undp.ac.id/16855/

Republika. 2018. Dana Zakat untuk Pembiyayaan Pertanian. Diakses $17 \quad$ September 2018 https://www.republika.co.id/berita/ duniaislam/wakaf/18/05/03/p84lqa374dana-zakat-untuk-pembiayaanpertanian

Republika. 2017. Al-Azhar Peduli Umat Bangun Rumah Rabuk di Desa Gemilang diakses dari https://www.republika.co.id/berita/ dunia-

islam/wakaf/15/02/17/njwna9alazhar-peduli-umat-bangunrumah-rabuk-di-desa-gemilang

Republika. 2016. LAZ Al-Azhar Cetak Petani Sejati. Diakses pada https:/www.republika.co.id/berita/ duniaislam/wakaf/16/09/08/od673s 396-laz-al-azhar-cetak-petani-sejati

Soeratno, \& Arsyad, L. (2003). Metodologi penelitian untuk ekonomi dan bisnis. Yogyakarta, Indonesia: UPP AMP YKPN.

Sudarto. (1996). Metodologi penelitian filsafat. Jakarta, Indonesia: Raja Grafindo Persada.
UU RI No. 23 tahun 2011 Tentang Pengelolaan Zakat

Wiryanitri, A. (2005). Peranan badan amil zakat sebagai pengelola zakat dalam upaya mengubah status mustahik menjadi muzakki menurut Undang-Undang Nomor 38 Tahun 1999 (Studi pada Badan Amil Zakat Kabupaten Sragen Propinsi Jawa Tengah). Universitas Diponegoro [M.A. Thesis]. Retrieved from http://eprints.undip.ac.id/11098/

Yusuf Qardhawi. 2011. Hukum Zakat. Ter, Bogor: Pustaka Litera AntarNusa.

Ning Karya Wijaya

Institut Agama Islam Negeri Surakarta

Indonesia

ning_k83@yahoo.com

Lila Pangestu Hadiningrum

Institut Agama Islam Negeri Surakarta

Indonesia

lilahadiningrum@gmail.com 